University for Business and Technology in Kosovo

UBT Knowledge Center

UBT International Conference

2016 UBT International Conference

Oct 28th, 9:00 AM - Oct 30th, 5:00 PM

\title{
Protection of minorities in international politics
}

Ilir Zylfiu

University for Business and Technology, ilir.zylfiu@ubt-uni.net

Fadil Osmani

University for Business and Technology

Follow this and additional works at: https://knowledgecenter.ubt-uni.net/conference

Part of the Social and Behavioral Sciences Commons

\section{Recommended Citation}

Zylfiu, Ilir and Osmani, Fadil, "Protection of minorities in international politics" (2016). UBT International Conference. 38.

https://knowledgecenter.ubt-uni.net/conference/2016/all-events/38

This Event is brought to you for free and open access by the Publication and Journals at UBT Knowledge Center. It has been accepted for inclusion in UBT International Conference by an authorized administrator of UBT Knowledge Center. For more information, please contact knowledge.center@ubt-uni.net. 
Book of Proceedings

International Conference on Social Sciences, Humanities, and other sciences

\title{
Protection of minorities in international politics
}

\author{
Ilir Zylfiu ${ }^{1}$, Fadil Osmani ${ }^{2}$ \\ ${ }^{1}$ UBT - Higher Education Institution, Lagjja Kalabria, 10000 p.n., \\ Prishtine, Kosovo \\ ${ }^{2}$ Kosovo Telecom \\ ilir.zylfiu@ubt-uni.net
}

\begin{abstract}
The problem of the protection of minorities was raised as an issue in the Treaty of Versailles, completed at the end of the war by the major Allied powers. The Allies had imposed certain obligations on the treatment of minorities to such states that had them in their territories. They also forecasted a trusted international organization with universal character, the League of Nations, the mission to ensure the protection of European minorities. Since the fall of the Berlin Wall and communist regimes, Europe was a eitness nationalism outbreak. Whole regions were covered with ethnic conflicts which were a serious threat to the stability and unity of Europe. Today, each in its field of responsibility, the OSCE, the Council of Europe, the European Union, are coordinating their efforts to develop a coherent system for the protection of national minorities. So, protection of minorities is an important factor for the stability and unity of Europe.

Western Balkan aspirant countries are a multi-ethnic society. The latest international analyses on guide us to the fact that some Western Balkan countries aspiring of becoming EU members, judging by the EC progress, lag in the implementation of the part of the Copenhagen political criteria that deals with respecting of minority rights. As it is well-known human rights and minorities remain an objective of the European Union in its foreign policy. European Union at the beginning of XXI century has been committed wth multiple projects to stability and economic development in cooperation between the countries of the region.

The purpose of this paper is to address the institutional protection of minorities in international politics, to understand the protection of minorities will discuss the historical aspects of the protection of minorities. His paper will be analyzed and international Documents concerning the protection of minorities. Special attention will be paid to the policy of international institutions, including the EU in relation to the protection of minorities. The research was conducted analysis methods and relevant materials.
\end{abstract}

Keywords: minority, the constitution, the law on minorities, the education law.

\section{Protection of minorities in international politics}

The issue of minority protection is imposed due to the number of states with mixed population in terms of ethnicity, religion, language or race. Minorities have existed throughout the history of mankind. Regardless of how they are created states, few are those that can be considered as homogeneous states. In general, states face internal diversity, as language, race, religion etc. Coping with ethnic minorities 
is a very complex issue, not only for the state but also for the international community. Given the historical analysis, we can consider that the issue of minorities has become a cause of conflict, both within the state, as well as those interstate. The causes of these conflicts lie in the fact that minority groups make an effort to preserve their identity, on the one hand, and the state, claiming to preserve the ethnic compactness. Minorities were and can be cause of interstate conflict, which come as a result of territorial claims to each other's countries. Therefore, the question of protection of minorities is a challenge to international politics. With the issue of the protection of minorities are taken and taken international institutions, adopting the relevant documents.

\section{1. $\mathrm{UN}$ in relation to the protection of minorities}

Within the UN there is a large number of bodies, which deal with human rights, while some of them with the rights of minorities. Most of them work under the aegis of the Economic and Social Council. Among the subsidiary bodies, are of particular importance for the Commission on Human Rights, SubCommission for the promotion and protection of Human Rights, Working Group on Minorities, the UN High Commissioner's human rights etc. ${ }^{16}$

According to the UN Charter, the main bodies dealing with minority issues are RA and the Economic and Social Council. ${ }^{17} \mathrm{UN}$ adopted a large number of documents, which directly or indirectly affect the issue, the position and protection of minorities. Among these documents, important place: the UN Charter, the Universal Declaration of Human Rights, International Covenants on Human Rights (1966), the Declaration UN on the rights of persons belonging to national minorities or ethnic , linguistic (1992).

The UN Charter, the UN Charter is the most important document of international law. San Francisco was signed on $06 / 26 / 1945$, and entered into force on 24.10.1945. ${ }^{18}$ Cards epilicite does not deal with the position of minorities. Its approval is understood to be working on strengthening human rights and this will contribute and provide the status of ethnic minorities and others. For him, it does not mention anywhere minorities and their protection. ${ }^{19}$

International Covenant on Civil and Political Rights (1966) - International Covenant on Civil and Political Rights contains many provisions on human rights and guaranteeing them. It is very important, after confirming non-discrimination, inter alia, on race, color, language, religion, national origin (Article 2/1). In the field of protection of minorities, and the most important provision is legally binding article 27 of the International Covenant on Civil and Political Rights, which states: "In states where there are ethnic, religious or linguistic minorities, persons belonging to such minorities shall not be denied the right to have, along with other members of the group, the lives of particular cultural, preach and practice their religion or to use their own language ".

UN Declaration on the rights of national minorities or ethnic, religious and linguistic minorities (1992): Declaration on the rights of national minorities or ethnic, religious and linguistic minorities was adopted in December 1992 by the UN General Assembly's Declaration, try to establish a balance to

${ }^{16}$ Krivokapić,B., Zaštita Manjina, u medjunarodnom i uporednom pravu, Kjnjiga 1, Novi-Sad, 2004,, fq. 390.

17 Dokumeti Organizacije Ujedinjenih Nacije - Pvelje Ujedinjenih Nacija 1945, Boris Krivokapić, Zaštita Manjina..., Knjiga 1, fq. 547-548.

${ }^{18}$ Bashkurti, L., Institucionet ndërkombëtar dhe Nismat rajonale,Tiranë, 2010, fq. 156.

19 Thornbery, P., Amor Martin Estebanez, M. , Minority rights in Europe,Minority rights in Europe, Strsbourg Cedex, 2004,f.12; 
Book of Proceedings

International Conference on Social Sciences, Humanities, and other sciences

ensure a protector of minority status and willingness to determine these rights, in order to not interfere with the freedom of action of the state. The statement said two opposite meanings, on the one hand is concerned about the position of minorities (who are often faced with the resurgence of nationalism), while the other side is ready to prevent the risks of disintegration of states, ethnic conflict. ${ }^{20}$ On the issue of minorities are important international agreements and conventions, including the Convention on Prevention and Punishment of the Crime of Genocide (1948), the UN Convention on the Rights of the Child (1989) etc.

\section{The most important documents of the Council of Europe for minority issues}

Within the Council of Europe have been prepared and approved a number of international agreements, recommendations and documents, which in various ways affect the issue of minority protection. The largest number of deals does not deal directly with minority issues, but contain provisions that are relevant to general prohibition of discrimination, inter alia by language, religion, nationality, etc. origin. Within the Council of Europe have concluded international agreements that affect the issue of minorities, the European Cultural Convention 1954 European Charter of Local Self-Government in 1985. There is no doubt that of all the agreements within the Council of Europe, which is directly related to the issue of Minorities is the European Charter for Regional Languages 1992 and the Framework Convention for the Protection of National Minorities.

\section{European Charter for Regional or Minority Languages:}

The idea for the preparation and approval within the Council of Europe of an international agreement for the protection of regional or minority languages has come from various factors, primarily of historical importance, the risk that impending regional languages or minority disappear, The einalienable rights of the minority language use in public and in private. The protection and promotion of minority languages is an important contribution to building a Europe based on the principles of democracy and cultural diversity. Member states of the EC, on 5 November 1992 adopted the European Charter for Regional or Minority Languages. ${ }^{21}$

European Charter for Regional Languages aims to protect languages. It should be noted that the European Charter for Regional Languages aims to protect not ethnic or linguistic minorities. Obviously that its implementation will influence the position of minorities, but the main goal is the preservation Card linguistic diversity, as one of the most valuable elements of European culture. ${ }^{22}$

Cards that traditionally refers languages are in use in European territory. These are traditional languages that are traditionally used in defined geographical districts. The charter does not deal with

${ }^{20}$ Benoit-Rohmer,F., Çështja e minoriteteve në Evrop, Tiranë,1996, fq. 26.

${ }^{21}$ Preambulla e Kartës Evropiane mbi Gjuhët Rajonale dhe Minoritare; Patrick Thornbery and Maria Amor Martin Estebanez, Minority rights in Europe,f.138.

${ }^{22}$ Krivokapić, B. , Zaštita manjina u regionalnim okvirima i putem bilateralnih sporazuma, Knjiga 2 , Novi-Sad, 2004, fq. 48. 
Protection of minorities in international politics

the new languages are presented in the Contracting States as a result of immigration, but as with local dialects.

Charter has its weak sides, as it allows the contracting states themselves to choose the provisions that oblige. Unlike other agreements, the card does not oblige countries to fully accept the agreement, but allows to accept only those provisions that are acceptable. It should be noted that card, though you can definition of regional or minority languages, not specify which European languages correspond to the concept. $^{23}$

European Charter for Regional or Minority Languages contains provisions that refer to education, judiciary, administration, public services, media, cultural, economic and social life etc. The Charter states that no provision violates any provision or other similar international agreements.

Approval of the charter has contributed to improving the climate for other agreements on the position of ethnic minorities. Soon after the Charter of Regional or Minority Languages was opened for signature on important regional document - the Framework Convention for the Protection of National Minorities.

\section{The Framework Convention for the Protection of National Minorities:}

The Framework Convention for the Protection of National Minorities has been accepted by the Committee of Ministers in 1994, while on 02.01.1995 was opened for signature by member states of the EC. For the first time it is an international agreement at regional level in this field. Framework Convention is an international instrument that is legally binding. As a contracting party may enter only EC member states and non-member states, who are invited by the Committee of Ministers of the EC. The Convention does not deal with the collective rights of minorities, but only with the rights of members belonging to the collectivity. Framework Convention states that "persons belonging to national minorities can exercise individually and together with others the rights and freedoms flowing from the principles enunciated in the Convention - within" (Article 3/2) ${ }^{24}$ It is important to emphasize that the convention - within not recognize minority rights, but formulates them in a way which imposes obligations of states towards minorities.

A very important issue is international mechanism of follow up the implementation of the Convention - within. This issue is regulated by Article 24-26 of the Convention - within. The Contracting States shall meet the obligations in the way of reports. The final decision on these reports gives the Committee of Ministers of the COE, which helps the Expert Advisory Committee. There are three game reports: 1. The first (initial) 2. regular (periodic) and 3. extraordinary reports (ad hoc). State that has ratified the convention is obliged to submit within one year the Secretary General of the EC's first report, which contains the measures taken to implement the Convention - within. After that, the state is obliged to submit periodic reports every five years. The Committee of Ministers may ask the state report 'ad hoc' in terms of implementation of the Convention. It asks the Committee of Ministers when the extraordinary report of the Advisory Committee of Experts recommend. Expert Advisory Committee receives information from various sources. When dealing with all the information, the Advisory Committee of Experts gives an opinion on the report and sends it to the Committee of Ministers for

\footnotetext{
${ }^{23}$ Neni 1 i Kartës i Kartës Evropiane mbi Gjuhët Rajonale dhe Minoritare.

${ }^{24}$ Konventa Kuadër për mbrojtjen e e Pakicave Kombëtare, Tiranë, 1996; Patrick Thornbery and Maria Amor Martin Estebanez, Minority rights in..., 2004, f. 89.
} 
consideration. In the end, the Committee of Ministers makes recommendations. Within the EC there is a large number of documents, which directly or indirectly affect the protection of minorities.

\section{OSCE and the issue of minorities}

Under the support of the OSCE have brought a series of important documents for the international rights and international relations, such as the Final Act of Helsinki (1975), the Charter of Paris for a New Europe (1990), the Convention for Peace and Arbitration (1992) etc.

Minorities mentioned for the first time in the Helsinki Final Act (1975). ${ }^{25}$ In addition, within the principle VII it stated that "participating state in whose territory national minorities exist, respect the right of persons belonging to such minorities to equality before the law, give full opportunity to enjoy effectively human rights and fundamental freedoms and in this way protect their legitimate interests in this field ". ${ }^{26}$ The OSCE has paid great attention to the issue of protection of minorities, because the specified European countries unresolved problems in the field of minorities may be an important factor to armed conflict. Among the many documents of special importance still belongs to what is accepted in the Copenhagen Conference in 1990, the second meeting of the Conference on the Human Dimension. In this statement confirmed minority protection standards. ${ }^{27}$

States have expressly agreed that respect for minority rights, as part of the rights of the human rights is an important factor for peace, stability and democracy in the participating countries. Copenhagen Declaration states that members of national minorities have the right to exercise their human rights and fundamental freedoms without discrimination and in full equality before the law; Participating states would agree to take special measures to ensure full equality with citizens of other minorities in the implementation $\mathrm{f}$ the experience of human rights and fundamental freedoms. It noted that the members of national minorities may exercise their rights individually as well as together with members of their group. In this way there is the realization of the rights recognized collectively. Like all other documents of the OSCE, the Copenhagen Declaration has no binding force and expresses rather a political commitment.

Copenhagen Declaration commitments are confirmed in the Charter of Paris for a New Europe (1990)..$^{28}$

Member states of the CSCE had decided that cooperation in the field of minority protection to continue with a conference of experts, which would have to specify the principles of the Copenhagen Document. The meeting ended in July 1991 with the adoption of a report, which clearly shows that the conference did not produce the expected results. This is due to attitudes conceptual participating countries between Western European countries, Central and Eastern Europe to recognize the existence of minorities on their territory (one of which was France and fear that recognition of the rights of the minorities can lead to impact border). In these circumstances, experts drafted a report which stated that "the diversity of situations and constitutional systems in Europe requires different treatments of problems" and that it is important to settle in those regions where democratic institutions are in the process of consolidation

\footnotetext{
${ }^{25}$ Akti Final i Helsinkut 1975

${ }^{26}$ See Principle VII: "Respect for human rights and fundamental freedoms, including free thought, conscience, religion and belief".

27 Thornbery , P. , Amor Martin Estebanez, M. , Minority rights in Europe ,.f.17.

${ }^{28}$ See more: Pariska Povelja za novu Evropu (1990): Boris Krivokapić, Zaštita manjina..., Knjiga 2, fq. 462-464.
} 


\begin{abstract}
.$^{29}$ This document, Albania has attached a statement, in which it states that the document was "only refers to national minorities and has nothing to do with the issue of the Albanian population of Kosovo in Yugoslavia", which makes the population the third largest in the state multinational and not the issue of national minority, but national issues. ${ }^{30}$

The document of the meeting of the Third Conference on the Human Dimension of the CSCE (Moscow, November 3, 1991) showed that the issue of clarifying the rules for the protection of minorities in a way has been completed and as key issues submitted to the full implementation of the provisions of a Document Copenhagen and the report of the Expert Meeting. Conference proceedings in Moscow makes more efficient mechanism guarantee human dimension. Moscow Conference speeds visibility procedure respecting the human dimension of the states. ${ }^{31}$ Future attention was focused on the creation of mechanisms for the protection of national minorities. ${ }^{32}$
\end{abstract}

\title{
6. High Commissioner on National Minorities
}

To ensure a more effective protection of minority rights, the Helsinki Document of the Conference (1992) provides that the Council of Ministers may appoint the High Commissioner for Minorities. So, the High Commissioner on National Minorities is an institution of the CSCE, directly specified for the protection of minorities. The High Commissioner appointed by the Council of Ministers of OSCE consensus, the proposal of the Permanent Council, for a period of three years, with the possibility of renewal.

The main purpose of the High Commissioner is not the protection of minorities in accordance with existing international standards, it does not monitor how participating States implement the obligations regarding the protection of minorities. ${ }^{33}$ The High Commissioner is authorized to collect and receive information on matters of national minorities; Visit any participating country and to communicate directly with stakeholders to get first-hand information; to evaluate the role, the nature of the tensions and the potential consequences for peace; confer with the parties and if necessary to advance the dialogue between them. The main purpose of the High Commissioner is to maintain security and peace in the region, and not care about the rights of minorities as such. ${ }^{34}$

\section{The European Union and the protection of minorities}

European Union on the issue of minority protection has two approaches, policies and practices in the internal and external. So, it is about the issue of minorities within the EU member states and countries that are not part of the EU. In the EU there is a significant number of documents dealing with the fight

${ }^{29}$ Florenc Benoit - Rohmer, vep. e cit, fq. 29.

30 Të drejtat e njeriut në të drejtën ndërkombëtare, akte themelore të Këshillit të Evropës dhe KSBEsë, Tiranë, 1994, fq. 282.

${ }^{31}$ See more: Florenc Benoit - Rohmer, vep. e cit, fq. 30-32.

32 Dokument trećeg sastanka Konferencije o ljudskoj dimenziji KEBS (Moskva, 1991, Boris Krivokapić, Zaštita manjina..., Knjiga 2, fq. 471-472.

33 Thornbery P., Amor Martin Estebanez, M. , Minority rights in Europe ,f. 18; Krivokapić, B., Zaštita manjin u regionalnim okvirima i putem bilteralni sporazuma, Knjiga 2,Novi Sad, 2004, fq. 82.

${ }^{34}$ Po aty, fq. 83. 
Book of Proceedings

International Conference on Social Sciences, Humanities, and other sciences

against discrimination, racism, xenophobia. ${ }^{35}$ Despite what has been important for members of minorities, the fight against discrimination is not the same for the protection of minorities.

In internal relations, the EU gives priority to the issue of combating racism, xenophobia, anti-Semitism. In other words, the problem of the protection of minorities has neglected. The EU has not defined policy, nor accepted standards regarding the protection of minorities. Certain countries of the EU (eg France), there are not only willing to accept specific obligations regarding minorities, but do not accept that exist on their territories such collectivities. ${ }^{36}$ For these reasons, the EU has no rules dealing with minorities.

Charter of Fundamental Rights of the EU (2000) contains no provision for minorities.

EU institution that dealt with the problems of minorities European Parliament, which has brought various acts, such as the Resolution on measures for the benefit of linguistic and cultural minorities (1983); Resolution on the languages and culture of ethnic minorities and regional (1987) etc. Besides parliament, other institutions do not deal with the problems of minorities. ${ }^{37}$

The EU has been very active in solving the problem of protection of minorities abroad. Since 1990, and especially since 1995, the EU has trade agreements build clauses that respect human rights. Such agreements contain provisions for the protection of minorities. ${ }^{38}$

Respect for minority rights by the EU is set as a condition for admission to this organization. The European Council, meeting in Copenhagen (1993) has established criteria that candidate countries must meet. Political criteria provided in the respect and protection of minority rights. ${ }^{39}$ Concern for minorities is shown in certain ways and in various initiatives under the influence of the EU, such as the Pact for Stability in Europe (1995); Stability Pact in South Eastern Europe (1999), International Conference OT ex - Yugoslavia and Arbitration Commission (Badinter Commission) etc. ${ }^{40}$ It should be mentioned that the EU has funded various programs to improve the position of minorities.

From analyzes of the EU's approach to minority issues we can judge that in fact it is about double standards. Meanwhile, when it comes to its members, the EU avoids dealing with this issue, while foreign policy is active. Its activity is seen in trade agreements, in its programs, as well as countries that have the political criteria for membership.

Stability Pact of Southeast Europe was established in 1999. Its activity extends into three areas: 1. Democracy and human rights, development and economic cooperation 2, 3. Safety. Within these, a special place occupies the protection of minorities. Among the 250 projects, a large number of them have been directly related to cooperation in the field of minorities. ${ }^{41}$ Central European Initiative (CEI) is the oldest organization national regions, which relates to cooperation with Central and Eastern Europe after the fall of communist regimes. It was founded in 1989 in Budapest. ${ }^{42}$

When it comes to minorities, all members of CEI's are run by the UN Charter and all documents of the OSCE. Within the CEI there are special working groups for minorities. The working group on the issue of minority cooperates with all international institutions such as the EC, EU, OSCE, the Venice

35 Thornbery , P. , Amor Martin Estebanez,M. , Minority rights in Europe..,f.20.

${ }^{36}$ Krivokapić, B. , Zaštita manjina u regionalnim ..., Knjiga 2, Novi-Sad, 2004, fq.105.

${ }^{37}$ See more: Krivokapić, B. , Zaštita manjina u regionalnim .., Knjiga 2, Novi-Sad, 2004, fq. 105-107.

${ }^{38}$ Po aty, fq. 108 .

39 Reka, B. , Gjeopolitika dhe teknika e zgjerimit të UE-së, Bruksel, 2010, fq.282-283; MehmetiKamberi, L. , Shteti kanditat i Bashkimit Evropian, Tiranë, 2011, fq. 143-145.

${ }^{40}$ See more: Milo, P. , Bashkimi Evropian, Tiranë 2002, fq. 276-280.

${ }^{41}$ http:/stabilitypact.org/.

${ }^{42}$ Bashkurti, L. , Institucionet ndërkombëtare..., fq. 137. 
Commission, the Working Group at the UN minorities etc. The working group has brought political document "CEI instrument for the protection of minorities" (1994). The instrument has 30 articles that regulate issues of importance to the protection of minorities. ${ }^{43}$

From all this can be endless that the international community has had and has focused on minority issues. In the protection of minorities are taken in various institutions, are drafted and approved documents.

\section{SOURCES AND LITERATURE}

\section{Published sources:}

- $\quad$ Akti Final i Helsinkut (1975).

- Deklarata e Kombeve të Bashkuara për të drejtat e pjesëtarëve të minoriteteve kombëtare, ose etnike, fetare dhe gjuhësore (1992).

- $\quad$ Karta e Kombeve të Bashkuara, 26. 6. 1945.

- Karta Evropiane e Qeverisjes Vendore.

- Karta Evropiane për Gjuhët Rajonale, ose të Pakicave.

- Karta Kuadër Për Mbrojtjen e Pakicave Kombëtare, Tiranë, 1996.

- Konventa Kuadër e Këshillit të Evropës për Mbrojtjen e Minoriteteve Kombëtare (1995).

- Pakti Ndërkombëtar për të Drejtat Civile dhe Politike, 16 dhjetor 1966.

\section{Literature}

- Bashkurti, Lisen, Institucionet ndërkombëtare dhe nismat rajonale, Tiranë, 2010.

- Benoit-Rohmer, Florence, Çështja e minoriteteve në Evropë, Tiranë, 1996.

- Krivokapić, Boris, Zaštita Manjina u medjunarodnom i uporednom pravu, Knjiga 1, Novi-Sad, 2004.

- Krivokapić,Boris, Zaštita manjina u regionalnim okvirima i putem bilateralnih sporazuma, Knjiga 2, Novi-Sad, 2004.

- Mehmeti-Kamberi, Lendita, Shteti kandidat i Bashkimit Evropian, Tiranë, 2011.

- $\quad$ Milo, Paskal, Bashkimi Evropian, Tiranë 2002.

- Reka, Blerim, Gjeopolitika dhe teknika e zgjerimit të UE-së, Bruksel, 2010.

- Thornbery, Patrick and Maria Amor Martin Estebanez, Minority rights in Europe, Strasbourg, Cedex, 2004.

\section{Sources from the Internet:}

- http:/stabilitypact.org/.

- http:/www.ceinet.org/vidw/02/02_12.htm.

\footnotetext{
${ }^{43}$ See more : http:/www.ceinet.org/vidw/02/02_12.htm.
} 